\title{
A STUDY ON FATHER AND SON RELATIONSHIP IN NICHOLAS SPARKS' DEAR JOHN
}

\author{
Nisa Amalina Sabrina*
}

\begin{abstract}
ABSTRAK
Dear John merupakan novel karya Nicholas Sparks, seorang penulis dari Amerika. Hubungan antara ayah dan anak yang terjadi di novel ini merupakan salah satu elemen penting yang membuat cerita dalam novel ini berkembang. Ini adalah sebuah interpretasi dari elemen - elemen intrinsik cerita dalam upaya untuk memahami hubungan antara ayah dan anak yang terjadi di novel ini. Pendekatan objektif digunakan karena analisis berkutat dengan elemen - elemen intrinsik novel. Metode yang digunakan dalam studi ini yaitu studi pustaka yang berfokus pada karya sastra itu sendiri dan materi tertulis yang ada di perpustakaan dan diinternet yang dapat mendukung analisis. Hasil akhir menunjukan bahwa banyak faktor yang mempengaruhi perkembangan hubungan antara ayah dan anak. Komunikasi dan kemampuan pribadi untuk memahami satu sama lain merupakan dua hal yang paling penting dalam hubungan ayah dan anak agar hubungan tersebut dapat berjalan dengan baik.
\end{abstract}

Kata kunci: hubungan, ayah dan anak, komunikasi, pemahaman

\begin{abstract}
Dear John is a novel American writer Nicholas Sparks. The relationship between father and son in this novel is one of the most important element that makes the story develops. It is an interpretation of the intrinsic elements of the story. The objective approach is chosen because the analysis deals with the intrinsic elements of the story. The method used in the study is library research which focuses on the literary work itself and the written material found in the library and the internet to support the analysis. The final result shows that there are a lot of factors that influence the development of the father and son relationship. The communication and the ability of each person to understand each other are two of the most important factors that influence the relationship of the father and son.
\end{abstract}

Keywords: relationship, father and son, communication, understanding

\section{INTRODUCTION}

Literary work is generally classified into two: 'serious' or high literature and popular literature. As an opposition to the term 'serious', popular literature is generally perceived as having lower quality than high literature. There has been a widespread assumption that popular literature is not worth studying, because popular literature is said to simply emphasize pleasure for readers and commercial aspects for the authors. As the product of popular culture, popular literature was produced for the enjoyment and the satisfaction of people. The main purpose of popular literature is entertainment and pleasure. Due to the fact that popular literature is read by a great number of people, doing a research on popular literature is important. 
Dear John released in 2006 is one of Nicholas Sparks' bestselling novels. It is a romance novel which is written in the firstperson point of view. The novel is divided into three parts; part I is the beginning, part II the conflicts and part III the ending. The story is about a young man named John Tyree. He lives with his single father who is a man of routine, talks less and is socially awkward. His father likes to collect coins and this is his only topic of conversation with John. John says that he and his father are not close and are unable to communicate well since he was a child. John decides to join the army to make his life better. Then, during a furlough, he returns to his hometown and falls in love with a girl he meets by the beach. The girl's name is Savannah. She is the reason why John is able to understand his father's real condition. Because of her, he is able to connect with his father on a whole new level that he never had. He starts to love, respect and truly appreciate all the wonderful things his father struggled to provide for him while he was growing up.

Commonly in a romance, the love relationship between a couple is the most prominent part that builds the story. Since Dear John is classified as a romance, the love relationship between John and Savannah has become the most interesting part of the novel that makes a lot of people read the novel, but the relationship between the father and the son is also interesting to read. How the father and son relationship develops, and how they get to know each other better also become important parts to develop the story. In Dear John, It is not only the love relationship between John and Savannah that attract people to read the novel but also the relationship be- tween members of family, in this case John and his father, that make this novel interesting to read. Thus the present writer is interested in knowing how the father and son relationship develops in this novel.

The objective of this journal is an attempt to study the father and son relationship in Nicholas Sparks' Dear John. More specifically it attempts to find out the development of the father and son relationship in the story and to find out the factors that make their relationship develop. In relation with the objective, the focus of examination is the father and son relationship and its development as seen in Nicholas Sparks' Dear John. Since this journal examines father and son relationship in Nicholas Sparks' novel, Dear John, the scope of the study covers the plot and the characters; John Tyree and his father. To enrich the analysis, the theories of character and plot are also discussed.

However, popular literature is a product of popular culture that is based on the reader's feeling and opinion about the text, it is important to study it by focusing on the literary work itself without relating it to the social background or the author's background. In the book entitled Critical Theory Today: A User-friendly Guide, Lois Tyson says:

\section{Quotation 01}

"The text itself" became the battle cry of the New Critical effort to focus our attention on the literary work as the sole source of evidence for interpreting it

(2006, p.136)

Based on the theory, all literary work, including popular literature, has the world of its own. Thus, it is important to find a concrete 
and specific example from the text itself to help the readers understand the literary work without relate it to the real world. The use of the specific evidence in the text can help the readers to validate the interpretation of the text itself. This kind of study is called close reading. (p.135)

Since the subject matter of this graduating paper is the father and son relationship in Nicholas Sparks' Dear John, the present writer uses the concept of close reading and applies the objective approach. This approach is the guideline to analyze the relationship between the major character and his father in Dear John. Objective approach is also known as intrinsic approach because the primary focus of this method is on the intrinsic elements, like plot, setting, and characters. It is an approach that analyzes literary work without relating the work to the author and the social condition. This approach considers that a literary work has nothing to do with certain issues, current happenings or critics in the past or present time. The story has its own meaning and stands for itself.

\section{The Development of the Father and Son Relationship: The Relationship in the Ear- ly Years}

This part is the father and son relationship when John Tyree is still a child. Born in a small town of Wilmington, North Carolina in 1977, John is raised solely by his father because his mother left them a little while after he was born. John never tries to find out about his mother since he knows that his father does not like to talk about her. He thinks that his father does not want to talk about his mother because it will make him remember about the past and it will make him sad. He thinks that his father will talk about his mother when he is ready to talk about her. So he never asks anything about his mother.

Growing up without having a mother figure in his life, John does not feel any different from other kids who have both a father and a mother. He feels that growing up only with his father is not a big deal. He thinks that their relationship is as common as the relationship between any father and son. He spends his weekend traveling around the town with his father; they go shopping in the shopping centers or go to the beach together. As a child, John never thinks that living only with his father is unusual. He knows how hard his father is trying to raise him on his own, but his father never complains, even when John disappoints him. John rarely gets hugs and kisses from his father because his father is not a type of a father that shows his emotion or feeling a lot. Apart from that John knows that his father loves him. His father shows his feeling by his devotion in taking care of John.

Back then, John and his father share the same passion, collecting coins; it makes their relationship strong. That is why John likes to spend his time talking about coins with his father.

\section{Quotation 02}

In time, I could tell how many Saint-Gaudens double eagles were minted in 1927 as compared with 1924 and why an 1895 Barber dime minted in New Orleans was ten times more valuables than the same coin minted in the same year in Philadelphia (Chapter I, p.14-15)

At this stage, they have a good relationship, since they do a lot of things together and 
they share the same passion. His father plays a very good role as both mother and father. As a child, John never feels that he lacks love and care since his father gives him enough attention and love. He thinks that his father is enough for him. They are close to each other because they have common things to share.

\section{The Changes in the Relationship: The Dif- ferent Ways of Thinking}

John's and his father's relationship goes well in the beginning. They never think that they are different from any other family, but problem starts to rise and make a change in their relationship. It starts when John becomes a teenage and his way of thinking starts to change. He starts to have interest in new things but his father does not introduce and tell him about them. He learns how to surf and to swim by himself and he does his project work by himself. Unlike the other fathers who show interest to their son's daily activities, his father rarely asks him about his day in school or his progress in doing his school projects. Mostly, he learns something by himself. It creates a distance in their relationship. John wants to learn other things rather than collecting coins, while his father only knows about how to collect coins. This is not because his father does not want to teach John about it but it is because his father does not know about something that John is interested in. John has to be independent by trying to learn by himself. For John, learning things from his father is not enough for him that is why he starts to learn by himself. If he can not do it on his own, he tries to fulfill his curiosity about the other things from others.

At this point, John realizes that he and his father are different.

\section{Quotation 03}

I suppose I should have realized then how different I was from my dad, but that just shows how little you know about life when you're a kid (Chapter I, p.11).

There is a different way of thinking between John and his father. His father is passive and introvert, but John is always on the move and hates to be alone. While John's father places a high value on education, John always thinks school is like a social club with sports added to it. The difference between John and his father makes their relationship drift apart. John likes to spend his time outside, while his father likes to spend his time at home with his coin collection.

John thinks that his father would have been better suited to be a monk than a parent because his father is very quiet, and seldom shows his emotion. He never gives John hugs, kisses or tells him that he loves John.

\section{Quotation 04}

He was the quietest man l've ever known. He asked few question about what was going on in my life. And while he rarely grew angry, he rarely joked, either(Chapter I, p.12).

His father rarely spends his times outside the house. He does not socialize and he spends long hours alone every day. He does not date and he also does not have friends to hang out with. He likes to do the same things repeatedly.

\section{Quotation 05}

He lived for routine. He cooked me scrambled eggs, toast and bacon every single morning and listened as I talked about school over a dinner he'd prepared as well. He scheduled visits to the dentist two months in advance, paid bills on Saturday, did the laundry on Sun- 
day afternoon, and left the house every morning at exactly 7:35 a.m. (Chapter I, p.12)

John's father's only passion in life is coins. He spends most of his time looking at his collection. For John's father, every coin has its own story. He thinks that it is the memory behind every coin that makes them important. In his youth, John did not mind his father's weird obsession of coins. Even his grandfather had the same obsession, so for John, it was nothing unusual.

As John grows up, he loses his passion in coins. He finds out that there are a lot of things outside that are more interesting than coins. Instead of talking about coins with his father, he prefers to hang out with his friends. Like most boys, he starts to care about other things like sports, girls, cars, and music.

John starts to feel the difference between his family and other families. He feels jealous of other children's families and he feels like an outsider amongst his friends. When he spends time at his friends' houses, he finds himself hating the fact that he does not have what they have. It is not only the lack of family members that bothers him, but also the way they live.

\section{Quotation 06}

Little by little, I began to notice differences in the way we lived when I compared myself with most of my friends. While they had money to spend to go to the movies or buy a stylish pair of sunglasses, I found myself scrounging for quarters in the couch to buy myself a burger at McDonald's. More than a few of my friends received cars for their sixteenth birthday: my dad gave me an 1883 Morgan silver dollar that had been minted in Carson City. Tears in our worn couch were covered by blankets, and we were the only family I knew who didn't have cable television or microwave oven. (Chapter I, p. 15)

John has to be independent in order to get what he wants while his friends are spoiled by their parents. John's friends get all they want because their parents provide them with the things they need, while he has to work for the things he wants. Their friends receive full attention and warmth from their parents, while his father is emotionless and rarely shows his feeling to John. John never gets spoiled by his father. His father does not know what is happening around him and he also does not know about the modern technologies that are popular at that time. He does not know how to spoil his son with material things.

John is embarrassed at the thought of having friends come over and he blames his father for that. He hates his father's odd behavior. He hates his house because his house is very old-fashioned. The furniture in his house is old and worn out. He does not have a house like his friends', that is full of modern things like computers, nice sofas, and so on. He hates his life and this realization makes him change his behavior. He used to be a good student and active in sports but then he turns into a rebel. John feels that his life is harder because of the fact that his father is very peculiar. Some people even call him weird or a freak. He changes his behavior because he is disappointed with his family's condition that is different from that of his friends'.

His father senses that something is changing, but he does not know what to do. He tries to make their relationship better in his own way. He tries to talk to John, but the only topic he can come up with is about coins. His effort 
to make their relationship better is not working, since John does not want to talk about coins anymore. When John tries to talk to his dad about football practice and the games, he can see that it just makes his father uncomfortable. His father once goes to the game but because of his unusual outfit and the strange behavior, he only makes John embarrassed thus pretending not to know him. John thinks that his father is not someone whom he can be proud of because he cannot act like a normal father.

This changes of the relationship happen also beacuse John starts to know how a normal family should be and he wants his father to act like a normal father who shows attention to his son, willing to tell new things and learn it together, spoils his son by buying what his son wants and able to express his feeling to him. But his father can not give what John wants. What his father knows is only collecting coins and he knows nothing about his son's interests. That is why John prefers to spend his time outside rather than at home. Causing them to rarely spend time together and have a conversation. This makes them stay apart.

\section{The Emergence of a Gap in the Relation- ship}

Things between them get worse when John's rebellion reaches the highest point. This is during his senior years when he loses his focus and goal in life and starts to get involved in fights and fails his classes. When he is taken home by the police because of getting into trouble, his father does not yell at him. John only sees the disappointment in his father's eyes and it makes him hate the world even more. Causing trouble seems to be the only way John knows to release his anger and frustration. This is also the only way to make his father aware of his existance. He thinks that by doing bad things he can catch his father's attention. So he takes the wrong action to attract his father's attention.

After graduating from high school, John does not go to college although his father has tried to persuade him to. He starts working, going from one job to another. John's father is a very introvert person and he never shows his emotion to John. That is the reason why he can not show and communicate his disappointment to John.

John's father never really tells John about his thought about John's decision. He does not know the best way to express his feelings and does not want to make things worse. He is not a type of a father that tells his son how to do things according to him is right. He lets his son decide what he wants to do with his life. He does not have control over his son and he does not want to make the relationship between them gets worse. So eventhough, John's father feels disappointed about John's decision not to continue his study, he does not say anything about it. He always keeps everything to himself and never shares his thoughts with John. Rather than arguing about John's decision and making their relationship worse, he tries to make the relationship between him and his son better. He tries to make a conversation with John, but the only topic that rises is about coins. He tries to engage John in another discussion about coins, but he fails.

John has had enough of his father and his coin collection. He can not understand his father's passion for coins. When his grandfa- 
ther died, he had left all of his coins to John's father, but instead of selling it to get money for their life; his father just keeps them and keeps collecting more and more coins. His father values coins more than anything. John never understands why his father really loves his coins and never tries to make a better life by selling those coins. He thinks that collecting coins is only a hobby and coins are not precious things to have. He values coins when he was a child because he thinks that it is interesting to have a hobby as collecting coins. But now he thinks that having a brand new car, good furniture and the other material things is more important than having those coins to collect. Coins do not make him rich and have a lot of friends. Coins do not make him a popular guy in school. This infuriates John and he lashes it out to his father. He never wants to talk about coins ever again.

His father says nothing but the fact that he is disappointed and hurt is clearly seen in his face. He does not show his disappointment by yelling at John or getting angry. But the way he acts after that moment shows that he is disappointed. He spends more of his time alone and never talks to John about the coins.

John's father realizes that John grows up and starts to change his way to value things. He has his own standard about what he thinks important and what is not and it is different from those of his father's. John as a young man thinks that the thing that he needs in order to be happy is money. While his father thinks that money and the other material things are not important. He values his coins collection not because it can make him rich but because every coin he possesses has a precious story behind it. The story that is more important than the coin itself. His father thinks nothing is wrong in his life and he does not need the material things to make him happy, but John thinks it is not enough, he needs money so that he can hang out with his friends. He needs an expensive car so that he can brag to his friends. He needs new furniture and modern electronic devices so he will not feel embarrassed when his friends visit his house.

Since that moment, their relationship gets worse, up to the point that they never talk to each other. They do not talk to each other often, no one tries to make a conversation after that moment. John prefers to spend time outside rather than being at home with his father. His father spends most of his time in his Den with his coins and still doing his routines. The different ways of thinking cause a gap between them. Since the only topic that he and his father usually talk about is coin and now John does not want to talk about it anymore so the communication between them gets worse. There is no topic to share. It makes the situation in their house become awkward and they feel uncomfortable being in the same place together without saying anything.

The relationship between John and his father is not getting better since John decides to join the army. It is one night before he decides to join the army.

His father becomes one of the reasons of his decision to join the army. John thinks that it is better to leave his house and let his father alone. He thinks that his father feels uncomfortable and burdensome when John is around him. He also feels that he is uncomfortable living in his house with his father. The 
relationship between them will not gets better if both of them do not communicate. That is the reason why John wants to join the army. He wants to give both of them space and time to think about themselves. It is better to live at a distant rather than being at home and making both of them feel uncomfortable about each other's existence.

In the first year John joins the army, he rarely contacts his father. $\mathrm{He}$ is too busy to do the training and to adapt to the soldier life. In addition, he has to move from one place to another. He has to move to Louisiana for a few months and he has to go to Germany afterward. Later on, he moves to Macedonia, then Kosovo. John becomes very busy and he does not have time even to call his father. Communication is very important in order to make a relationship works well, but because of these things the communication between John and his father becomes difficult to do and their relationship does not go well.

At this point, there is not any progress in their relationship. Instead of making it better, John's decision to join the army only makes a gap between them wider and makes communication between them become impossible. John is very busy as a trainee soldier and his father has no initiative to make their relationship better. John's father does not want to disturb John and his new life as an army personal. They live their own life in different ways as if they are strangers to each other.

The Reconciliation of Father and Son Relationship

The third stage of the development of the father and son relationship is the reconciliation. It is the most significant development in their relationship. The relationship between John and his father is getting better. It is the turning point that happens in their relationship. This turning point is divided into two stages, which are: The new beginning of their relationship, and the revelation of the cause of the bad relationship between the father and son.

\section{The New Beginning of the Relationship}

John joined the army as a lost and angry man, and he feels that the army has changed him. He stops smoking and his drinking habit slowly decreases. He turns into a responsible and mature man. Living in the army changes his way of thinking towards life and people around him. He starts to understand how important having someone at his side while he has to live a hard life. He values the life he has and thinks that life is not always about material things and money. He becomes a person who is responsible to his duty and loyal to his team. He then realizes that he can not live alone in this world. He needs someone to rely on and someone to share his thoughts and problems with. He starts to realize that he needs his father who is always there when he needs someone to share his problems.

His father also realizes that he misses John. Even though they rarely talk when they around each other, he misses John's existence in their house. When John is shipped to Germany, his father, though their relationship is still not that of a regular father- son, writes to him once a month.

At this point, his father also changes. He takes the initiative to send a letter to John. He starts to show his attention to his son. His father sends him a letter because he misses 
John and he wants to know about John's life during his service in the army. It shows that his father also tries to make the communication between them works by taking an initiative to contact John. They gradually send letters to each other telling their conditions and sharing their daily story to each other.

In his letter, John knows that his father is curious and worried about him. It shows when John writes about firefight that happens when John was in the Balkan. His father writes back to say that he is glad that John survived, but said no more about it. In order to make his father not worry about his's condition, John never talks about the risk that he should take while in the army.

There is a mutual improvement that happened between John and his father. They start to leave their ego and try to understand each other. John does not want his father to worry about him so he writes things that do not make his father worried. John's father also writes general things about himself so that John knows that he is doing well at home. They try to compromise with each other, so that their communication goes well without making each other worried.

In every letter his father promises that he will write again soon. This bridges the gap between them and it is then that John realizes what a good man his father is. In his mind, his father, though strange, will always be a better man than he will ever be.

At this point, they start to realize how important the existence of each other. They start to think that they need each other in their life. Even though they are two different people who have different ways of thinking and different personality, they realize that family is something that cannot be broken up. Being separated from each other makes them realize that the relationship between father and son does not change even though they have different perspectives in life.

During the break, John decides to go home. This first meeting after a long separation makes his father awkward. His father does not recognize him at first. Instead of offering a hug, he only shakes John's hand and asks him about the flight.

He observes that nothing has changed since he first left for the army. The conversation has developed since the last time they met. They have a good conversation during dinner. John tries to make a good initiative to open the conversation. They talk about John's friend Tony, who is in love. They talk about his father's retirement and so on. However his father only gives brief comments but John feels glad he can make a nice conversation with his father.

At this point, their relationship shows some progresses. They never argue about things anymore. Their relationship goes back to the point where they are living together as two different people and try to understand every difference they have. John spends most of his afternoon outside, going to the beach or just wondering around the town and his father never complains about that. He also lets John borrow his car. John and his father always have dinner together and talk about the general things that happen in their lives. John tells him about his new friend Savannah and how they spend most of their time together. His father always asks question like "How was your day?" "How'd go last night?" and so on. It shows his father's attention towards 
John's life and he is happy because he feels that they can pay more attention toward each other in their own way.

At this stage, John realizes that people have to understand each other well in order to make a relationship better. Their relationship will not go well, if they are still egoistic. It will never work if they still do not care for each other. John knows that his father is a type of a person that is very passive and introvert. That is why he tries to approach his father first by asking questions about his daily activities. He realizes that the most important thing to make their relationship better is by having a good communication.

One day, John decides to invite Savannah to his house. He wants to introduce her to his father.

\section{Quotation 07}

Once my dad got over the shock of my return with Savannah in tow and the introductions were made, he ran quick hand over his wispy hair and stared at the floor(Chapter 6 , p. 108).

His father is shy, as always, and even though he tries to make conversation, he seemed to be lost and uncomfortable. He does not feel comfortable dealing with new things. That is why when Savannah comes to their house he feels awkward and uncomfortable. He is not the type of a man that can easily make friends. He needs time to be open with new people and feel comfortable around them.

The first time Savannah comes to John's house, it surprises John how good she is with his father. They spend forty minutes in the den. John's father tells Savannah about his coins collection and Savannah looks interested.

\section{Quotation 08}

She asked dozens of questions, questions either I or any book on coin collecting could answered, but as minutes passed, her questions became more subtle. Instead of asking why a coin might be particularly valuable, she asked when and where he'd found it (Chapter 6, p.109)

John's father looks very excited while telling the story about how they got the coins to Savannah. He tells the story about their trip to find coins. He talks a lot about all those coins for an hour and he looks so enthusiastic. It is like he has kept the story by himself for a long time and he cannot stop to talk about it.

John never sees this side of his father for a long time. There is a passion in his eyes when he tells those stories about his coins. The passion that is lost from his eyes since they stopped talking about coins. Looking at his father acting like that makes John happy too. He does not really care about the coins, $\mathrm{He}$ is concerned more about his father's expression when he tells the stories about the coins and it makes him feels so happy, because his father smiles brightly. Savannah really knows how to make a conversation with John's father. She shows a curiosity about John's father's coins and it makes John's father open and talk a lot to her. She asks many questions about his coins and he answers all of her questions enthusiastically. John realizes that it is easy to make a conversation with his father. He just has to talk about something that his father like and know about. John realizes that if he wants to work on the relationship with his father, he has to stand in his father's shoes. He has to deal with his father's interest. So that he can understand him 
more and it can make their relationship better. John has changed into a mature man. $\mathrm{He}$ used to be selfish and does not care about his father's feeling and interest. He prefers to be a rebel to catch his father attention but now he want to deal with those things as long as it can make his father happy. Now he does not only think about himself but also think about his father. He tries to understand his father and deal with him to make their relationship better.

After the meeting of his father and Savannah that night, the atmosphere in their house is nicer than ever. John smiles for no good reason all the time. John's father also cannot hide his feeling, he looks so happy too. The relationship between them also goes so well. They cannot stop talking about Savannah and the conversation goes so natural with no one feeling forced to talk about it. His father is willing to listen when John endlessly talks about Savannah even though it takes a couple of hours.

Savannah has brought a change in John and his father's relationship. Savannah affects the way John sees his father. Before that, John thinks that his father is someone that is difficult to deal with. He thinks that he can not understand his father. He can not get along with him. But now he learns from Savannah how to deal with his father. It is not impossible at all to make a good conversation with his father. He realizes that actually his father is a simple-minded person. He also finds out things that make his father happy and he is willing to deal with that as long as it can make his father happy and make their relationship go well.

\section{The Revelation of the Cause of the Bad Relationship}

As a student studying autism, Savannah finds that John's father has the characteristics of a person with Asperger's syndrome. Asperger's syndrome is a mental disorder that makes it difficult to interact with other people. It was a type of autism, which explains his obsession for coins and his daily routines that are out of the ordinary.

\section{Quotation 09}

"I'm not an expert," she said, "but this book was assigned both semesters that I had her, and I must have studied it every night. Like I said, she's interviewed more than three hundred adults with disorders" (Chapter 9, p.140).

She says that she spends a lot of her time in the lab hours working with children who have Asperger's. She also has met a number of adults his professor had interviewed. She says that John's father is very similar to a couple of them. This information makes John furious. John can not accept the fact that his father is retarded.

It means that even though he knows that his father is strange and different from any other fathers, he cannot accept that someone says something bad about him. He cannot accept that his father is retarded. He thinks that his father is as normal as the other, he only has a strange behavior, but he is a normal person. He respects his father more than anyone. He thinks that his father is a great father.

$\mathrm{He}$ is angry to Savannah whom, he thinks, takes advantages of his father for her research about that disorder. Savannah tries hard to make John understand and accept the 
facts about his father but John keeps denying the fact about his father's disorder.

Although John knows that his father is different; he does not have friends, and never hangs out. He does not like talking to others, and deal with new things and he likes to do the same things, he still respects his father. He feels offended with Savannah's statement about his father. He knows his father is strange, but he thinks nobody is perfect. His father, with all of his strange behavior he has, is still his father and no one can say bad things about him or take aim him as an object of a research. At this point he thinks that he has to protect his father.

The next day, Tim, Savannah's best friend, comes to John's house. John apologizes because he beats him and tells him the reason behind his misbehavior. After knowing the reason why John did that Tim tells him that he understands it. He tells John that he also has a little brother who has Asperger's Syndrome. He says that they also have a hard time to accept the fact. But later on, they realize that by accepting the fact about that, it makes them easier to deal with a person who has that syndrome. It can help them to understand his little brother more. It also does not change their love for him. Accepting and learning about his condition can help make things easier between them.

This statement makes John realizes that his father's disorder is not a sin. It is something that he has to accept. He starts to read a book about Asperger's syndrome that Savannah gave him. When he is at home, he observes his father. He always wakes up at the same time every morning, makes breakfast the same way, reads the newspa- per in the same order. He has the same job for all his life. He has the same house, the same furniture, and the same clothes. He always makes dinner at the same time, and every week it will be the same menu for certain days. He realizes that maybe Asperger's syndrome is the answer to his question. He realizes that this too is probably the reason his mother left them. It is not his fault that he does not have a social life or that he can not converse like other people in general. Knowing all this, he realizes that his father is a good man and he does his best to take care of him under the circumstances. It also changes John's perspective toward his father and he realizes that he can understand his father better. He thinks that he has to support his father and comfort him in order to make it easier for him to live his life. He starts to understand his father better and it makes it easier to work on their relationship.

\subsection{The Mature Relationship of Father and Son}

After knowing the fact about his father's disorder, John is able to understand him better and tries harder to improve their relationship. The relationship between John and his father grows stronger when John decides to accept his father's condition even when it gets worse. John's perspective about his father changes when he decides to accept his father's condition. He respects his father more than before he knows the truth about his father's condition. He does not blame his father about his condition. Thus he can not have the normal relationship between a father and a son. But John is satisfied with the relationship they have. He is proud to be his 
father's son whether he is sick or not. Knowing all this, John believes that he can improve the relationship between him and his father better.

John tries to make a conversation with his father but his father answers his question briefly as usual. John has a feeling that his father wants to continue the conversation but does not know how to. So John tries to help his father to make their conversation better. So he asks his father to show some coins that he bought lately. It is the first time John asks about coins to his father after a long time. His father looks so surprised but then he said 'okay'.

At this point, John already knows about the cause of his father's strange behavior. He thinks that he has to understand his father even more. He places himself as the one who has to compromise with the situation. $\mathrm{He}$ has to deal with his father's condition to make their relationship better. He starts to give attention to the things that his father likes.

Their relationship becomes better day by day with their ability to understand each other. It is the time for John to go back to the army. In the morning, his father drives him to the airport and before John leaves; he hugs his father and says that he loves him. This is the first time in their relationship he takes the initiative to show his love to his father directly.

\section{Quotation 10}

I hugged him instead. His body was rigid, but I don't care. 'Love you, Dad'

'I love you, too, John.'

'Find some good coins, okay?' I added, pulling back. 'I want to hear all about them.'

He glanced at the floor. 'I like Savannah,' he said 'she's a nice girl.' (Chapter 11, p.167)
John feels surprised. It feels weird at first, hearing his father expressing his feelings towards something. His father likes the girl that John loves. His father gives him his approval to John to date with Savannah and it makes the relationship between John and Savannah goes well even though they have to have a long distance relationship because John has to come back to the army. For the relationship between John and his father, it is the first time for them to have an emotional moment and shows their love towards each other. But their relationship has grown into the next step, the better one.

During the army, John and his father regularly send letters to each other. They talks about their daily life. John's father sends longer letter than before. And it makes John happy.

In this point the relationship between John and his father reaches the next stage. They are able to understand each other and fit themselves in the same level, they tries to make their relationship looks normal and natural in their own way by giving a good attention in each other interest. Their communication goes really well.

The year they are apart, the relationship between John and his father stays strong. They are more open up toward each other and express their emotion and feeling well. During his duty in the army, John realizes that he misses his father and he knows that his father does the same too.

In May, a few day before John was to return home, a letter came telling John to go home early because his dad had suddenly become ill from a heart attack.

John spends most of his break in his father side, taking care of him. As he stays with 
his father, he becomes closer to him. He can see his father feeling. Because of a tube inserted into his father throat, he can not speak. So john does all the talking for them. Mostly, he talks about coins, he reads his father books, and he goes home to take care of his father's coins collection as well.

At this point, John takes a responsibility of his father. He realizes that he is the only person that his father has in the world. As his only son, John realizes that his father does not have anyone to rely on but him. His father needs his help because he is the only person his father feels comfortable with. He is taking care of his father to show his respect toward his father. He realizes that his father can not live by himself. He needs help because of his disabilities and as a son, John feels responsible about that.

By the time he realizes that he is able to know his father more. When he tries to researched coins in the internet, he finds out that all the coins that his father has, has high valued. But his father lives very humble. He realizes that his father does not know about their value. He is not interested either. John knows that for his father the most valuable thing about his coins collection is the memories behind every coin. That is priceless. He is able to understand his father's thought about his hobby, collecting coins now.

\section{Quotation 11}

That to my dad, the pursuits of the coins was far more interesting that the coins themselves, and to him each coin was representative of a story with a happy ending. (Chapter 15, p.218)

He remembers all the moment he spends with his father when he was a kid; they searched for coins together and successfully found coins they wanted. All those memories they have when collecting the coins are neatly kept in every coins. He now realizes why his father values those coins so much. He realizes that his father is a good father. He feels so proud of his father. Realizing all that, his feeling toward his father is deeper. He loves his father more than anything now.

While their relationship becomes closer, John's father's health becomes worse. John is worried about him. After knowing his father condition is getting worse, John feels a need to improve the relationship between him and his father. He knows that they get along better these days than they ever had. But he wants to spend more of his time with his father. They spend hours together, without saying anything, and it is in this quiet, they realize that they finally become friends. They come to the point where they are comfortable with each other attendance.

The father and son relationship between John and his father is come to the point where they do not need to express what they are feeling. They are able to understand and to feel what the other feels toward each other. There are no boundaries between them. Their relationship is stronger than before.

He knows that his father is a good man, a kind man and though he has led a wounded life, he has done the best he can to raise John. He realizes that his father never raises him in anger. All the memories John has with his father starts to play in John's mind. He feels a big regret wasting all those years blaming his father. He remembers his last two visits home, all the best memories they has that time, and think that they will never share 
those moments again. It makes the tears can not stop. It breaks him.

Their relationship has become stronger. Together, they think they have strength to survive in the world. They give support to each other. John tries his best to stay strong for his father. But it is his father who gives him strength. Their relationship has reached the highest point when they think that they need each other in order to live in this world. They also feel comfortable with each other. With a heavy heart, John returns to the army, not knowing that that will be the last time he will ever see his father alive. His father dies seven weeks later.

\section{CONCLUSION}

In the novel, the father and son relationship is divided into four stages. The first stage is the relationship when John was still a child. They have a good relationship as a father and son. They can live together without a figure of a mother. They share the same passion and do a lot of things together. The second stage is when the relationship starts to change because of some reasons. In this stage there are some conflicts that come up and they change the relationship. They have to deal with the different ways of thinking. John and his father also have to live separately because of John's duty as an army officer and it makes a distant between them. The third stage is the reconciliation of the father and son relationship. It happens when they start to realize the mistake each has made and they try to under- stand each other. They start to compromise and work together to make their relationship better. The truth about his father's mental disorder also makes their relationship better. It makes them understand and care about each other more. And the last stage is the mature relationship between them. This is when they are able to understand each other and deal with each other's feeling and interest well. They realize that they need each other to live in this world. They care and feel comfortable with each other.

The father and son's relationship is influenced by the ability of both sides to understand each other. The most important thing in the father and son relationship is the communication. In order to make the communication work, both, father and son have to compromise with each other. Each can not only think about oneself but one also has to pay attention to the other. By doing that, the communication between them goes well and the relationship between the father and son works just fine.

\section{REFERENCES}

Abrams, M.H. A Glossary of Literary Term: Seventh Edition. United States of America: Heinle \& Heinle, a division of Thompson Learning, Inc, 1999

Abrams, M.H. The Mirror and the Lamp: Romantic Theory and Critical Tradition. London: Oxford University Press, 1953.

Sparks, Nicholas. Dear John. New York: Grand Central Publishing, 2009.

Tyson, Lois. Critical Theory Today: A User-friendly Guide -Second Edition.New York: Routledge Taylor and Francis Group, 2006. 